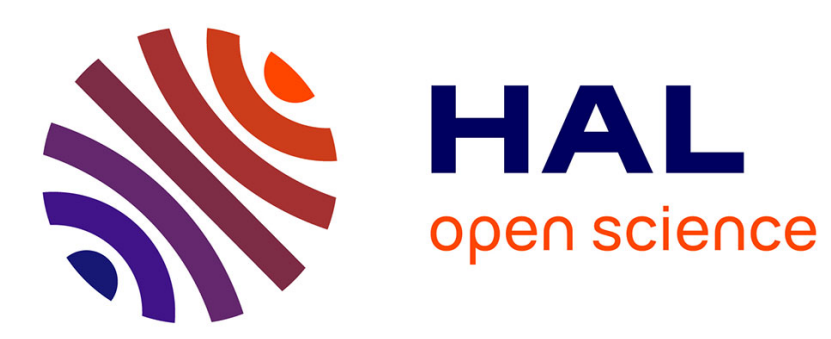

\title{
Is artificial intelligence associated with chemist's creativity represents a threat to humanity?
}

\author{
Jean-Louis Kraus
}

\section{To cite this version:}

Jean-Louis Kraus. Is artificial intelligence associated with chemist's creativity represents a threat to humanity?. AI \& Society: Knowledge, Culture and Communication, 2018, 33 (4), pp.641-643. 10.1007/s00146-018-0832-x . hal-02115338

\section{HAL Id: hal-02115338 \\ https://hal-amu.archives-ouvertes.fr/hal-02115338}

Submitted on 30 Apr 2019

HAL is a multi-disciplinary open access archive for the deposit and dissemination of scientific research documents, whether they are published or not. The documents may come from teaching and research institutions in France or abroad, or from public or private research centers.
L'archive ouverte pluridisciplinaire HAL, est destinée au dépôt et à la diffusion de documents scientifiques de niveau recherche, publiés ou non, émanant des établissements d'enseignement et de recherche français ou étrangers, des laboratoires publics ou privés. 
archives-ouvertes

\title{
Is artificial intelligence associated with chemist's creativity represents a threat to humanity?
}

\author{
Jean-Louis Kraus
}

\section{To cite this version:}

Jean-Louis Kraus. Is artificial intelligence associated with chemist's creativity represents a threat to humanity?. AI and Society, Springer Verlag, 2018, 33 (4), pp.641-643. 10.1007/s00146-018-0832-x . hal-02115338

\section{HAL Id: hal-02115338 \\ https://hal-amu.archives-ouvertes.fr/hal-02115338}

Submitted on 30 Apr 2019

HAL is a multi-disciplinary open access archive for the deposit and dissemination of scientific research documents, whether they are published or not. The documents may come from teaching and research institutions in France or abroad, or from public or private research centers.
L'archive ouverte pluridisciplinaire HAL, est destinée au dépôt et à la diffusion de documents scientifiques de niveau recherche, publiés ou non, émanant des établissements d'enseignement et de recherche français ou étrangers, des laboratoires publics ou privés. 


\title{
Is artificial intelligence associated with chemist's creativity represents a threat to humanity?
}

\author{
Jean-louis Kraus ${ }^{1}$
}

Published online: 5 March 2018

\section{The dream of the chemist}

Do you remember when Methistophiles caught Wagner bending over his smoking retort, and asked him "What is happening in here?"

Wagner replied, "Be quiet. A wonderful work is ready to be accomplished. The construction of man is underway" (Schöne 1994).

For many, many years, it has been the dream of chemists to create life from inanimate material. Now, there is the idea of something that thinks, even though it is not alive. In other words, we can now say that nothing separates the imaginary from the possible, nor the possible from the real. Those who think that "If I can imagine one thing, it is real," confuse the reality of an image with the physical and practical reality of the object that it evokes.

Which chemist starting from matter considered as inanimate matter (atoms or primitive simple molecules such as $\mathrm{HCN}, \mathrm{NH}_{3}, \mathrm{CH}_{4}, \mathrm{H}_{2} \mathrm{O}$, ) could have planned the structure of sophisticated complex molecules of life (nucleic acid, hemoglobin, proteins) that would be used for the creation of life on earth billions of years later?

Also imagine a smart organic chemist discovering new catalysts which would allow the reaction times to not be billions of years later, but whose synthesis could be achieved in just a few hours. The crucial question he would have to face would be "How could I make the right choice, among the $10^{60}$ possible structures, for the synthesis of a DNA molecule?" [National Research Council (US) 1988];today, it is known to produce hundreds of millions of molecules, while the number of potential candidate molecules would be between $10^{23}$ and $10^{60}$ (Reymond 2015).

Jean-louis Kraus

jean-louis.kraus@univ-amu.fr

1 Institut de Biologie du Développement de Marseille (IBDM), CNRS-UMR 7288-Aix-Marseille University, Campus de Luminy, case 907, 13288 Marseille Cedex, France
This same smart chemist would be in the same situation as that of a monkey being asked to type randomly on a typewriter keyboard the text of Shakespeare's "Hamlet". This contains 130,000 letters. The probability that the monkey would succeed in fulfilling this task would be of the order of $1 / 5 \times 10^{267,000}$. This means that Hamlet's text would only be successfully completed by an immortal monkey ("Monkeys Don't Write Shakespeare" 2018). Who would like to be this immortal chemist?

When Beethoven or Mozart wrote symphonies, their writing was infinite and their imaginations were without limits. In contrast, this poor chemist would have no choice. There is no way he could design the universe, which surrounds us, and others using the appeal of atoms and atomic theories.

Is there an essential boundary between the inert material and the living? Some people simplify living things to determine essential elements in terms of genome or metabolic networks. This can be considered as a top and down strategy. In contrast, some people want to simulate the origin of life in the tradition of prebiotic chemistry and adopt an upward bottom-up strategy. They try to reconstruct complex elements of the living from simple elements.

A significant example of bottom-up strategy is the following one:

Which organic chemist could have the idea to create a giant molecule like maitotoxin, whose structure $\mathrm{C}_{164} \mathrm{H}_{256} \mathrm{O}_{68} \mathrm{~S}_{2} \mathrm{Na}_{2}$ boasting 164 carbon atoms and 99 sites of stereoisomerism ( $2^{99}$ isomers !!!!), helps marine dinoflagellate species like Gambierdiscus toxicus to survive? (Nicolaou et al. 2014). It is worth recalling here the concepts developed by Kauffman in his fascinating book "At Home in the Universe," which explores new insights into the nature of life (Kauffman 1996).

At this point, the crucial question should be that organic chemistry should focus more on what and why, rather than on how to make it. But, this is becoming a less interesting question as the years go by, since very new softwares are now available to chemists and these speed up the synthetic 
process strategy. It should be underlined that these processes may lead to zombies and not to living autopoietic organisms as mentioned in the Maturana and Varala theory (Mingers 1991).

\section{Can artificial intelligence (AI) answer to these fundamental questions: What? Why? and How?}

One has to take into account that chemical transformations, which have been painstakingly entered into synthetic processes, have been discovered by organic chemists themselves. There is no way that an intelligent machine could have integrated Friedel-Crafts or Suzuki's coupling reactions in the synthetic process, unless those transformation reactions (which had been discovered by human chemists) had not been injected into the software of the intelligent machine.

AI could bring helpful answers to the question of how to make a chemical structure. But, these intelligent tools are not yet likely to match the creativity of top-level total synthesis masters. However, they can combine an incredible amount of chemical knowledge and are able to process it in intelligent ways, and with a rapidity that can never be matched by humans.

Let us look at intelligence as a thermodynamic function, one that is deeply linked to entropy.

The second law of thermodynamics states that "Entropy" $(S)$, a state function of an open system, is essential in predicting the extent and direction of complex chemical reactions, as the system evolves from its initial to its final state. The well-known Gibbs free energy equation (Gibbs 1873) $(\Delta G=\Delta H-T \Delta S)$ allows us to understand how and why entropy affects the evolution of various processes. Entropy has often been loosely associated with the amount of order or disorder in equilibrium systems.

Wissner-Gross and Freer reported that a deep link exists between entropy and intelligence (Wissner-Gross 2013). According to these authors, a relationship in the form of a causal generalization of entropic forces can cause two defining behaviors of the human "cognitive niche" These are the use of tools and social cooperation. The authors proposed a potentially general thermodynamic model of adaptive behavior as a nonequilibrium process in open systems.

\section{Innate intelligence and artificial intelligence}

Let us consider natural intelligence as the sum of two types of intelligence: critical and logical:
Natural human intelligence $=$ critical intelligence + logic intelligence.

Imagine a researcher who wants to use AI to help him in his research project. Since most of the augmentation of human thought tools act as analytical tools, or as a knowledge representation of formalism or method of reasoning or as a programing language (Troxell 1990), external artificial intelligence use should affect only the logic intelligence type.

Let us be even more daring and consider "intelligence" as a state thermodynamic law. When AI is introduced in this intelligence system, application of Gibbs's second law equation to this transformation from its initial state before AI introduction, and final state after AI introduction, leads to the following equation:

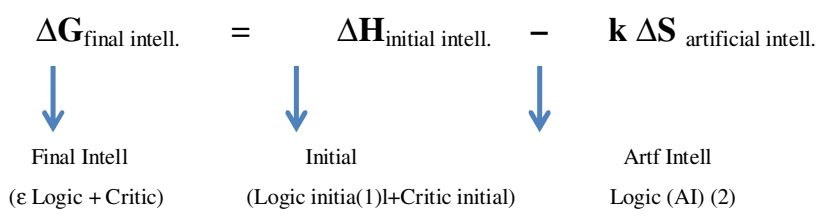

In this equation, $\Delta G$ represents the final human intelligence function: critical $+\varepsilon \operatorname{logic}(\mathrm{Nat}+\mathrm{Artf}), \Delta H$ represents the initial human intelligence function (critic and logic 1), which includes social, affective, political, sexual, poetic, artistic, and somatic forms. $\Delta S$ represents artificial intelligence (logic 2 ) as an entropic function.

Applying thermodynamics international convention, we can attribute a negative value to natural human intelligence. In contrast, depending on the quality of AI, negative or positive values can be attributed to it. Negative value in the case of AI strengthens the initial human natural intelligence, as one can expect. Positive value in the case of AI, brought to the system, is opposed to the spontaneous evolution of this system (weakness of the analysis software, inappropriate data bases, incompatibility language between the AI tool and the human working brain).

Four cases could be envisaged:

First: The formal logic intelligence brought by AI improves human cognitive behavior. In this case, addition to the consistent artificial logic intelligence introduced in the system leads to an increase of the resulting final intelligence, and $\Delta S$ should be negative $(\Delta S<0)$.

Second: Addition of unconsistent artificial logic intelligence $(\Delta S>0)$ to a researcher endowed with an average natural intelligence (logic and critic) has no effect on the system.

Third: Addition of consistent artificial logic intelligence $(\Delta S<0)$ to a researcher endowed with a high natural intelligence (logic and critic) leads to an increase of his natural intelligence, thus helping him in his research project. 
Fourth: Addition of inconsistent artificial logic intelligence $(\Delta S>0)$ to a researcher with low level of logic and critic intelligence can increase his difficulties in his research project.

Considering these four choices, who should be feared more: artificial intelligence or human cretinism? Cretinism is used here as an antonym of intelligence.

AI is a sharp form of logical intelligence but not critical intelligence. AI is supposed to bring speed and reliability to one of the most common functions of the human intellect, which consists in classifying the objects it perceives according to nomenclatures which are habitual to it. For a profound distinction between human and machine memory, see reference (Simondon 2016).

If AI looks intelligent, its intelligence results from human activity: (data base feeding, discriminant analysis software programs, calibration of the tool on the data...). AI represents an additional intelligence which can be harnessed with the strategic and logic creative insight of the human intelligence, for example, to discover drug molecules more quickly.

In the balance sheet, AI can be detrimental to the human society:

- First, if it amplifies the intelligence (critic and logic) of human beings with strong critical intelligence, on which society will have no more control.

- Second, if AI is added to human beings with low critical intelligence, who may misuse AI, then dangerous drifts to human society are to be feared.

\section{Conclusion}

Artificial intelligence associated with scientist creativity will represent a threat to humanity when it will reach a level of critical intelligence higher than that of human innate critical intelligence. Threat must be taken in the sense of how the complex of humans-society-technology will be transformed and how the 'humane' will redefined.

Threat being AI is probably much less to be feared than natural stupid intelligence. Moreover, are we sure that we are safe from the emergence of artificial stupidity?

Acknowledgements AMU University (Marseille) and CNRS (France) are greatly acknowledged for financial support. We thank Mrs Mair Richards for manuscript's English revision.

\section{References}

"Monkeys Don't Write Shakespeare" (2018) Wired News. Associated Press. 2003-05-09. Archived from the original on 2004-02-01. Retrieved 2007-03-02. https://www.wired.om/news/culture012 $84.5890 ? 00 \mathrm{html}$

Gibbs JW (1873) A method of geometrical representation of the thermodynamic properties of substances by means of surfaces. Trans Conn Acad Arts Sci 2:382-404

Kauffman S (1996) At home in the universe. Oxford University Press. ISBN-13: 978-0195111309\$4. ISBN-10: p 0195111303 [reprint edition (November 21, 1996]

Mingers J (1991) The cognitive theories of Maturana and Varela. Syst Pract 4:319-338

National Research Council (US) (1988) Committee on mapping and sequencing the human genome. National Academies Press, Washington, DC (ISBN-10: 0-309-03840-5)

Nicolaou KC, Heretsch P, Nakamura T, Rudo A, Murata M, Konoki K (2014) Synthesis and biological evaluation of 'QRSTUVWXYZA' domains of maitotoxin. J Am Chem Soc 136:16444-16451. https://doi.org/10.1021/ja509829e

Reymond J-L (2015) The chemical space project. Acc Chem Res 48:722-730 https://doi.org.10.1021/ar500432k

Schöne A (1994) Faust. Kommentare. Enthalten in: Goethe Faust. Deutscher Klassiker Verlag, Frankfurt am Main (ISBN 3-618-60270-7)

Smithers T, Troxell W (1990) Design is intelligent behaviour, but what's the formalism? Artif Intell Eng Des Anal Manuf J 4(2):89-98

Wissner-Gross AD, Freer CE (2013) Causal entropic forces. Phys Rev Lett 110:168702. https://doi.org/10.1103/Phys.rev.lett.110.168702

Simondon G (2016) On the mode of existence of technical objects. Univocal Publishing LLC (1 août 2016). ISBN-10: 1937561038. ISBN-13: 978-1937561031\$4 